\title{
Linkage of an Alternaria Disease Resistance Gene in Mandarin Hybrids with RAPD Fragments
}

\author{
Zeynel Dalkilic', L.W. Timmer, and Frederick G. Gmitter, Jr. \\ University of Florida, Citrus Research and Education Center, 700 Experiment Station Road, Lake \\ Alfred, FL 33850
}

\begin{abstract}
AdDITIONAL INDEX WORDS. breeding, BSA, Citrus reticulata, JOINMAP, PCR
Abstract. The inheritance of resistance to a host-specific isolate (Shinn) of Alternaria alternata (Fr.:Fr.) Keissl. from 'Minneola' tangelo (a cross between Citrus paradisi Macf. 'Duncan' and $C$. reticulata Blanco 'Dancy') was shown to be controlled by a single recessive allele, $a \mathrm{aM1}$, within the citrus genome. A backcross between resistant 'Clementine' mandarin $(C$. reticulata) and susceptible LB\#8-10 (a hybrid of 'Clementine' mandarin and 'Minneola' tangelo) resulted in 61 resistant $(\mathrm{R})$ and 58 susceptible $(S)$ plants $\left(\chi^{2}=0.0756, P \geq 0.05\right)$, but the reciprocal cross deviated from the expected 1R:1S ratio $(87$ $\mathrm{R}$ and $36 \mathrm{~S}$ plants $\left(\chi^{2}=21.1463, P \geq 0.05\right)$. A dominant allele, $A a M 1$, of this resistance gene was found in a loose coupling phase linkage with two RAPD markers, $P_{12}{ }_{850}(15.3 \mathrm{cM})$ and $\mathrm{AL3}_{1250}(36.7 \mathrm{cM})$, after JOINMAP computer analysis.
\end{abstract}

Alternaria alternata causes brown spot disease on susceptible citrus cultivars in Florida, Australia, South Africa, South America, Spain, Israel, and Turkey (Timmer et al., 2003). Since it was first recorded in a few scattered 'Dancy'mandarin (C.reticulata) groves in Polk and Highland counties in Florida in 1974, the disease has been causing serious economical losses in fruit yield on 'Minneola' tangelo trees (Whiteside, 1976), 'Dancy' mandarin, 'Orlando' tangelo $(C$. paradisi $\times C$. reticulata), 'Murcott' tangor (probably a $C$. reticulata $\times C$. sinensis hybrid), and 'Sunburst' tangerine $(C$. reticulata). The total 'Minneola' tangelo orchard area decreased 3\% in Florida from 1318 ha in 1996 to 1275 in 1998 (U.S. Dept. of Agriculture, 1998). Some of this decrease can be attributed to brown spot damage. Alternaria Nees species produces host specific toxins (HSTs) of which two major groups exist in citrus, A. citri Ellis \& N. Pierce tangerine (ACT)-toxins (Gardner et al., 1986) and A. citri rough lemon (C. jambhiri Lush) (ACR)-toxins (Kono et al., 1985). The target site of the ACT-toxins is the plasma membrane, and ACR-toxin- 1 is the mitochondrion (Kohmoto et al., 1993). Alternaria black rot of fruit and mancha foliar on 'Mexican' lime [C. aurantifolia (Christm.) Swing.] are two other alternaria diseases that damage citrus (Timmer et al., 2003).

Although use of disease-free trees and less vigorous rootstocks, well-timed irrigation, avoidance of excessive fertilization, and frequent light hedging are appropriate cultural practices for control, a reliable and continuous solution to this disease problem has not been found. Citrus cultivars vary genetically in their degree of brown spot disease resistance. 'Clementine' mandarin is very resistant to alternaria brown spot (Kohmoto et al., 1991), and thus, 'Clementine' was used in breeding alternaria resistant cultivars (Schutte, 1993). Susceptibility appears to be a dominant trait that is transferred from 'Dancy' mandarin to its progeny (Kohmoto et

Received for publication 21 Nov. 2003 Accepted for publication 13 Apr. 2004 Florida Agricultural Experiment Station Journal Series. The authors thank Drs. Zhanao Deng and Peng Ling, Ms. Margie K. Wendell, and Ms. Ana M. Ibanez for technical assistance, and Drs. Kevin M. Crosby, Neal E. De Vos, and Eliezer $\mathrm{S}$. Louzada for their critical review on the manuscript. This paper is based on a portion of a thesis submitted by Z. Dalkilic in partial fulfillment for the requirement for the PhD degree in Horticulture. Authors thank Adnan Menderes Univ. for providing a scholarship to the senior author for this research.

${ }^{1}$ Former Graduate Student. Present address: Adnan Menderes University, College of Agriculture, Department of Horticulture, 09100 Aydin, TURKEY.

Correspondence: e-mail: zdalkilic@adu.edu.tr al., 1991). For assessing susceptibility, in vivo (attached, intact) or in vitro (detached, cut) assay techniques can be used for disease resistance screening experiments with infectious spores or toxins of organisms (Canihos et al., 1998; Gardner et al., 1986; Kohmoto et al., 1991).

Many known citrus plant traits are inherited as dominant genes. For example, in Poncirus trifoliata (L.) Raf. tolerance to cold(Weber et al., 2003), salinity (Tozlu et al., 1999), and resistance to citrus tristeza virus (Deng et al., 1997; Fang and Roose, 1999; Fang et al., 1998; Gmitter et al., 1996), and citrus nematode (Tylenchulus semipenetrans Cobb.) (Gmitter et al., 1992; Hutchison, 1985; Ling et al., 2000) appear to be controlled by dominant alleles. Nevertheless, alternaria resistance is presumed to be controlled by a single recessive allele (Kohmoto et al., 1991) in citrus. Molecular DNA markers have been applied in citrus to find linkage with corresponding genes. Localized linkage maps were constructed for the citrus tristeza virus resistance gene, $C t v$, from $P$. trifoliata with RFLP (Fang et al., 1998; Mestre et al., 1997), RAPD (Fang et al., 1998; Gmitter et al., 1996; Mestre et al., 1997), and SCAR (Deng et al., 1997) marker systems. A novel gene, Ctv2, conferring CTV resistance in pummelo [Citrus maxima (Burm.) Merr.] was found (Fang and Roose, 1999). Ling et al. (2000) found RAPD and RGC (resistance gene candidate) markers linked to a citrus nematode resistance gene region (designated Tyr 1) in a Citrus-Poncirus backcross population.

The objectives of this study were to evaluate different citrus hybrid families for their resistance to alternaria brown spot disease by detached and attached leaf assays, to ascertain the inheritance of disease resistance, and to develop RAPD markers associated with gene(s) for resistance to alternaria.

\section{Materials and Methods}

Plants. From July to Sept. 1995, some of the mandarin-type hybrid families available from the University of Florida's Citrus Research and Education Center (CREC) citrus breeding programs were evaluated with detached leaf assay for their resistance to alternaria. The parents used in these crosses were as follows: 'Clementine'; 'Minneola' and 'Orlando' (both derived from 'Duncan' $\times$ 'Dancy'); 'Lee', 'Robinson', 'Nova', and 'Fairchild' (all four 'Clementine' $\times$ 'Orlando'); 'Fortune' ('Clementine' $\times$ 'Dancy'); 'Murcott' (most probably a mandarin-sweet orange hybrid of 
unknown parentage); 'Ortanique' (a natural hybrid of unknown parentage); LB\#8-10 ('Clementine' $\times$ 'Minneola'), and LB\#3-1 ('Clementine' $\times$ 'Murcott'); and 'Nakon' and 'Thong Dee' pummelo (Table 1). According to information obtained from the 1995 tests, new crosses were made to evaluate alternaria resistance in citrus hybrids in 1996. Detailed tests were conducted with reciprocal crosses of 'Clementine' with LB\#8-10, as well as LB\#8-10 with 'Minneola', 'Lee' with 'Nova', and LB\#8-10 selfed (Table 2). For these, a seedy clonal selection of 'Clementine', and 'Lee', 'Nova', and 'Orlando' [located in the Citrus Arboretum of the Florida Dept. of Agriculture and Consumer Services (FDACS), Division of Plant Industry (DPI), Winter Haven, Fla.], and LB\#810 (maintained at CREC) were used as parents in reciprocal crosses to obtain the hybrids for detailed investigation along with the other crosses. LB\#8-10 was obtained from a cross between 'Clementine' and 'Minneola' made by A.P. Pieringer in the mid 1970s. It produces only one true hybrid embryo per seed.

Conidia PRoduction, Plant InOCulations, AND LEAF ASSAYS. Production of inoculum and inoculation techniques were modified from Canihos et al. (1998) and Whiteside (1976). The Shinn isolate of Alternaria alternata was obtained from a leaf lesion from a 'Minneola' tangelo grove near Polk City, Fla., on 25 Apr. 1995 by L.W. Timmer. Monoconidial cultures were obtained and maintained either on sterilized Whatman filter papers (Whatman Intl., Kent, U.K.) at $-20{ }^{\circ} \mathrm{C}$ or on silica gel desiccant (Fisher Scientific, Fair Lawn, N.J.) at $4^{\circ} \mathrm{C}$. Cultures were grown on potato dextrose agar (PDA; Difco Laboratories, Detroit) for 3 to $5 \mathrm{~d}$ at $27{ }^{\circ} \mathrm{C}$. The surface of the plates was scraped with a scalpel to remove aerial mycelia and the colony was cut into approximately $2-\mathrm{mm}$-square pieces. Small pieces were transferred to each Petri plate of a sporulation medium consisting of $30 \mathrm{~g}$ $\mathrm{CaCO}_{3}, 20 \mathrm{~g}$ sucrose, and $20 \mathrm{~g}$ agar per liter of distilled water. Two milliliters of sterile, distilled water were added to each plate. The plates were sealed with Parafilm, and incubated for 3 to 5 d at $27^{\circ} \mathrm{C}$. Conidia were collected by adding $\approx 10 \mathrm{~mL}$ of sterile, distilled water to each plate and gently scraping the surface of the colonies with a small paint brush, then filtering the suspension through two layers of cheesecloth to remove mycelial fragments. Conidia were washed two times in sterile, distilled water into 50$\mathrm{mL}$ polycarbonate centrifuge tubes with round bottoms (Nalge Nunc International, Rochester, N.Y.) by centrifugation at $600 g_{\mathrm{n}}$ for $10 \mathrm{~min}$ to remove additional mycelia and any toxin carried over from the culture plates. The pellet in the bottom of the tubes was re-suspended in $40 \mathrm{~mL}$ of double distilled water and gently vibrated for few seconds. The conidia suspension was adjusted to $10^{4}$ conidia/mL using a hemacytometer, glycerol was added to the tubes ( $20 \%$ of the total volume), and the suspension was stored at $4{ }^{\circ} \mathrm{C}$ until used.

Young leaves from hybrids and propagated parent plants grown in the greenhouse were used for conidia inoculation experiments. When the seedlings produced new leaflets, the single, tender, leaf (1-2 cm long) closest to the shoot tip was collected from each plant and brought to the laboratory. Leaves were placed on their adaxial sides on metal screens within $300 \times 230 \times 100-\mathrm{mm}$ rectangular containers with tight fitting lids (crispers) (T295C; Tri-State Molded Plastic, Dixon, Ky.). Leaves were misted with the conidia suspension on their abaxial sides using a chromatography sprayer (Crown Spra-Tool; NorthAmerica Professional Products, Woodstock, Ill.). In some instances, droplets of conidial suspension were placed on the abaxial surface of the leaves by using a pipetter (Rainin Instrument Co., Woburn, Mass.). Double distilled water was sprayed or dropped onto control leaves. Distilled water was added to the crispers maintained in the laboratory during the incubation period to maintain high relative humidity. Lesions on susceptible leaves were observed $3 \mathrm{~d}$ after inoculation. The parent plants were included in each inoculation experiment. Plants were scored susceptible if any symptoms were observed. Leaves from symptom free plants were inoculated a second time to verify their resistance to the disease. For the attached leaf assay, hybrids grown and maintained in 96-cavity white plastic trays were cut-back, leaving two to three nodes above the soil level to synchronize new flush. The seedlings were placed in a growth chamber (Percival Scientific, Perry, Iowa) and kept at $27{ }^{\circ} \mathrm{C}$, $100 \%$ relative humidity, in the dark. Conidia suspensions were sprayed as described above. Three days after inoculation, plantlets were scored susceptible or resistant depending on the presence or absence of symptoms, respectively. Chi-square values were calculated for both assays.

Genomic DNA isolation and bULK PREParation. The DNA extraction method was modified for total DNA extraction from any age of leaves (Deng et al., 1996; Ling et al., 2000; Porebski et al., 1997): Leaves were ground in $18 \times 150-\mathrm{mm}$ glass test tubes with 2 mL lysis buffer $[1 \%$ cetyltrimethylammonium bromide (CTAB), $5 \%$ polyvinyl pyrrolidone (PVP), $1.4 \mathrm{M} \mathrm{NaCl}, 20 \mathrm{~mm}$ EDTA, 10 $\mathrm{mm}$ Tris- $\mathrm{HCl}$ (pH 8.0), and $350 \mathrm{~mm}$ 2-mercaptoethanol] using a BioHomogenizer M133/1281-0 (ESGE, Mettlen, Switzerland) for a few seconds. Samples were transferred into sterile 2.0-mLEppendorf tubes that were centrifuged at $1200 \mathrm{~g}_{\mathrm{n}}$ for $5 \mathrm{~min}$ at $4{ }^{\circ} \mathrm{C}$. The supernatant $(700 \mu \mathrm{L})$ was transferred to sterile 1.5-mL Eppendorf tubes. Equal volumes $(700 \mu \mathrm{L})$ of 25 phenol : 24 chloroform : 1 iso-amyl-alcohol (by volume) were added to the tubes and the supernatant $(600 \mu \mathrm{L})$ collected after centrifugation at $1200 g_{\mathrm{n}}$ for 5 min at $4{ }^{\circ} \mathrm{C}$. A second 25 phenol : 24 chloroform : 1 iso-amylalcohol extraction was performed and the supernatant $(500 \mu \mathrm{L})$ transferred to sterile 1.5- $\mu \mathrm{L}$ Eppendorf tubes. Equal volumes (500 $\mu \mathrm{L})$ of chloroform were added to the samples and the tubes were centrifuged $1200 g_{\mathrm{n}}$ for 5 min at $4{ }^{\circ} \mathrm{C}$. The supernatant $(400 \mu \mathrm{L})$ was transferred to sterile 1.5-mL Eppendorf tubes, 2.5 volumes $(1000$ $\mu \mathrm{L}$ ) of $95 \%$ ethanol was added and the DNA precipitated at $-4{ }^{\circ} \mathrm{C}$ overnight. The DNA was recovered by centrifugation at $4000 g_{n}$ for $15 \mathrm{~min}$. The DNA samples were rinsed with $70 \%$ ethanol, dried at room temperature, and re-suspended in $100 \mu \mathrm{L} 1 \mathrm{M}$ TE buffer (10 mm Tris-HCl pH 8.0, 1 mm EDTA). RNase (Sigma-Aldrich Co., St. Louis) was added ( $1 \mu \mathrm{L}$ of $\left.500 \mathrm{ng} \cdot \mathrm{mL}^{-1}\right)$, and the samples were incubated at $37^{\circ} \mathrm{C}$ at least $1 \mathrm{~h}$ in an incubator (model 133000; Boekel Scientific, Feasterville, Pa.). DNA concentrations were determined by analyzing 5- $\mu \mathrm{L}$ samples compared with standard uncut lambda DNA on a $1 \%$ agarose high EEO gel. DNA samples were adjusted to $50 \mathrm{ng} / 100 \mu \mathrm{L}$ with $1 \mathrm{~m}$ TE buffer.

Total DNA from five resistant and five susceptible hybrids from the 'Clementine' $\times$ LB\#8-10 backcross were bulked (Michelmore et al., 1991) and designated $\mathrm{R}$ and S, respectively. Twenty microliters of equilibrated DNA solutions from each hybrid were mixed in a 500- $\mu$ LEppendorf tube to construct each bulk, to be used for primer screening to identify possible RAPD polymorphisms.

RAPD-PCR SCREENING. RAPD fragments were amplified by using 492 single, random 10-mer oligonucleotide primers from the kits of A-H, O-X, AA-AN series (Operon Technologies, Alameda, Calif.), and DNA bulks as template. Each $15 \mu \mathrm{L}$ of PCR reaction mixture contained $20 \mathrm{~mm} \mathrm{MgCl}_{2}$ Ficoll dye, $200 \mu \mathrm{M} 10 \times$ dNTP mix (Idaho Technology, Salt Lake City, Utah), $0.8 \mu \mathrm{M} 10$ mer primer, 1 unit Taq polymerase enzyme (Promega, Madison, Wis.), $50 \mathrm{ng} \cdot \mu \mathrm{L}^{-1}$ genomic DNA, and dd sterile $\mathrm{H}_{2} \mathrm{O}$ (Welsh and McClelland 1990; Williams et al., 1990). The PCR was performed 
in a PTC-100 Programmable Thermal Controller (MJ Research, Watertown, Mass.). The PCR amplification program used was: $94{ }^{\circ} \mathrm{C}$ for $2 \mathrm{~min}$, then $94{ }^{\circ} \mathrm{C}$ for $1 \mathrm{~min}, 35^{\circ} \mathrm{C}$ for $1 \mathrm{~min}, 72^{\circ} \mathrm{C}$ for $2 \mathrm{~min}$, for 43 cycles.

The amplification products were separated on $1 \%$ high EEO agarose gels (Fisher Scientific Co., Pittsburgh, Pa.) prepared with $1 \times$ TAE (0.04 м Tris-acetate, 0.001 м EDTA) and poured onto a horizontal gel tray (model H4; Life Technologies, Gaithersburg, Md.). For staining, ethidium bromide was added to the agarose gel before the run and the gels were destained after the run. Amplified RAPD fragments were detected under an ultraviolet light transilluminator (UVP, San Gabriel, Calif.) and photographed using the IS-500 gel documentation system (Alpha Innotech Corp., San Leandro, Calif.). The score of " 1 " for each present fragment, and the score of " 0 " for each absent fragment, were assigned. The blank lanes were designated with "_.".

In the first test, resistant $(\mathrm{R})$ and susceptible $(\mathrm{S})$ bulks from only the 'Clementine' $\times$ LB\#8-10 cross were screened side-by-side with 492 RAPD primers. A second screening of 63 primers for the 'Clementine' $\times$ LB\#8-10 backcross, including their parents, was repeated. A third PCR screening, of bulk samples, parents, and their corresponding hybrids was run. After the third screening, all readable polymorphic fragments were scored, and used in the chisquare analysis to verify if the fit was acceptable. MAPMAKER (Lincoln et al., 1993) and JOINMAP(Stam and van Ooijen, 1995) computer programs were used to determine the linkage among the markers. The Kosambi mapping function with minimum 3.0 LOD score, and 0.35 linkage ratio, was used.

\section{Results}

In 1995, all of the hybrids obtained from 'Minneola' tangelo crosses with 'Clementine' mandarin, and with 'Nakon' and 'Thong Dee' pummelo, showed a positive reaction to the alternaria when they were inoculated with the Shinn isolate (Table 1). Hybrids between 'Lee' and 'Nova'gave an $\mathrm{F}_{2}$ type Mendelian segregation ratio of 1 resistant to 3 susceptible progeny. The same segregation

Table 1. Tests for Alternaria alternata (Shinn isolate) resistance of citrus hybrids in 1995.

\begin{tabular}{|c|c|c|c|c|c|c|}
\hline \multirow[b]{2}{*}{ Crosses } & \multirow[b]{2}{*}{ Model } & \multirow[b]{2}{*}{$\mathrm{R}^{\mathrm{z}}$} & \multirow[b]{2}{*}{$\mathrm{S}$} & \multicolumn{3}{|c|}{$\chi^{2}$} \\
\hline & & & & $\overline{0: 1}$ & $1: 1$ & $1: 3$ \\
\hline 'Clementine' × 'Minneola' & ss $\times$ SS & 0 & 9 & 0.00 & --- & --- \\
\hline 'Nakon' x 'Minneola' & ss $\times$ SS & 0 & 34 & 0.00 & --- & --- \\
\hline 'Thong Dee' $\times$ 'Minneola' & ss $\times$ SS & 0 & 32 & 0.00 & --- & --- \\
\hline 'Fortune' $\times$ 'Orlando' & Ss $\times$ SS & 0 & 12 & 0.00 & --- & --- \\
\hline ‘Nakon’ × LB\#8-9y & $\mathrm{ss} \times \mathrm{Ss}$ & 11 & 16 & --- & 0.93 & 3.57 \\
\hline LB\#8-8 × US119 & Ss $\times$ ss & 9 & 10 & --- & 0.05 & 5.07 \\
\hline 'Clementine' $\times$ 'Murcott' & ss $\times$ Ss & 1 & 3 & --- & --- & 0.00 \\
\hline LB\#3-1×x LB\#8-15 & Ss $\times$ Ss & 4 & 19 & --- & $9.78^{*}$ & 0.71 \\
\hline 'Lee' × 'Fairchild' & Ss $\times$ Ss & 4 & 18 & --- & $8.91^{*}$ & 0.55 \\
\hline 'Lee' × 'Nova' & Ss $\times$ Ss & 9 & 28 & --- & $9.76^{*}$ & 0.01 \\
\hline LB\#8-4 × Ortanique & Ss $\times$ ss & 13 & 20 & --- & 1.48 & $3.65^{\prime}$ \\
\hline LB\#8-8 × USDA15-60 & Ss $\times$ ss & 6 & 4 & --- & 0.40 & 1.20 \\
\hline LB\#8-4 × 'Orlando’ & Ss $\times$ SS & 1 & $13^{w}$ & --- & $10.29^{*}$ & 2.38 \\
\hline LB\#8-9 × 'Orlando' & Ss $\times \mathrm{SS}$ & 5 & $59^{w}$ & --- & $45.56^{*}$ & 10.08 \\
\hline 'Robinson' $\times$ 'Fairchild' & $\mathrm{Ss} \times \mathrm{Ss}$ & 2 & $23^{w}$ & --- & $17.64^{*}$ & 3.85 \\
\hline 'Nakon' × 'Page' & ss $\times$ Ss & 50 & $22^{w}$ & --- & $10.89^{*}$ & 1.19 \\
\hline
\end{tabular}

${ }^{\mathrm{z}} \mathrm{R}=$ resistant, $\mathrm{S}=$ susceptible.

yLB\#8__ from 'Clementine' $\times$ 'Minneola'.

$\times$ LB\#3-1 from 'Clementine' $\times$ 'Murcott'.

wAberrant crosses.

*Significant at $P \geq 0.05$. ratio was observed for the 'Lee' and 'Fairchild' hybrids. Most of the 'Orlando' hybrids and the hybrids from 'Robinson' and 'Fairchild' were susceptible. Disease symptoms in the 'Orlando' crosses developed late, and lesions were of fainter color than those from 'Minneola' crosses. Regardless of the seed parent, all progeny derived from 'Minneola' (SS) as susceptible pollen parent were susceptible. Crosses using 'Orlando' (SS) as pollen parent also produced only susceptible offspring. The few resistant progeny from the 'Orlando' cross may be from open pollination. Since LB\#8-4 × 'Orlando' and LB\#8-9 × 'Orlando' crosses did not fit the expected 0:1 ratio, the existence of another allele or locus besides aaM1 could be suggested (Table 1).

In 1996, both detached and attached leaf assays gave the same results for resistance/susceptibility in any particular individual (data not shown). Detailed tests were conducted with reciprocal crosses of 'Clementine' with LB\#8-10, as well as LB\#8-10 with 'Minneola', 'Lee' with 'Nova', and LB\#8-10 selfed (Table 2). Sixty-one plants showed no symptoms and were scored as resistant, while 58 showed symptoms and were scored as susceptible $\left(\chi^{2}=0.08, P \geq\right.$ $0.05)$, in agreement with the expected 1:1 ratio in the 'Clementine' $\times$ LB\#8-10 backcross. The segregation of disease resistance (87 resistant : 36 susceptible) within the LB\#8-10 with 'Clementine' backcross population was different from the reciprocal cross. The chi-square value, $\chi^{2}=21.15$, for $1: 1$ segregation was highly significant at the $P \geq 0.05$ level. The 'Lee' $\times$ 'Nova' cross revealed 42 resistant and 128 susceptible progeny fitting the 1:3 expected ratio $\left(\chi^{2}=0.01\right)$. All 183 hybrids from the LB\#8-10 $\times$ 'Minneola' cross were susceptible, as predicted. Although selfing progeny of LB\#8-10 did not yield enough sexual hybrids, disease resistance evaluation showed five resistant and six susceptible individuals. Alternaria disease resistance was concluded to be a recessive single gene trait based on the results.

RAPD fragments were treated as dominant markers in PCR analyses. Because some primers produced both faint and strong fragments, a second round of screening was thought necessary for eliminating the fragments that were amplified by mismatching. Only nine primers gave clear and scorable polymorphisms between paired bulk samples. In a third round of screening, the 'Clementine' $\times$ LB\#8-10 cross produced 11 markers from seven primers. Both MAPMAKER/ EXP v3.0b (data not shown) and JOINMAP v2.0 (Table 3) gave very similar results. A total of six markers linked in three linkage groups from five primers were found to be associated with alternaria resistance in 89 hybrids of the 'Clementine' $\times$ LB\#8-10 backcross. The chi-square test showed that $\mathrm{AL}_{1250}$ and P12 850 segregated in a $3: 1$ ratio $(66: 23$ and $61: 28, \chi^{2}=0.03$ and 1.98, respectively, $P \geq 0.05$ ). $\mathrm{AN6}_{650}$, $\mathrm{V} 3_{1500}, \mathrm{~S} 9_{800}$, and AL $3_{1600}$ showed 1:1 segregation $\left(\chi^{2}=1.90,2.91\right.$, 1.36 , and 1.36 , respectively, $P \geq$ $0.05)$. Two markers, AL $3_{1250}$ and $\mathrm{P} 12_{850}$, and the putative dominant gene locus, named $A a M 1$, were linked to susceptibility, covering 
a $36.7 \mathrm{cM}$ region. If RAPDs are dominant, a 3:1 ratio is expected, but both parents are heterozygous for the RAPD allele, i.e., Ss $\times$ Ss (Table 3). No interference between the markers was presumed. Although these two RAPD markers were linked to the AaM1 locus, the genetic distances were large. In the second linkage group, the genetic distance between markers $\mathrm{AN6}_{650}$ and $\mathrm{V} 3_{1500}$ was $5.7 \mathrm{cM}$. In the third linkage group, the markers $\mathrm{S} 9_{800}$ and $\mathrm{AL}_{1600}$ were $6.7 \mathrm{cM}$ apart. The other markers, $\mathrm{S} 9_{1000}, \mathrm{D} 12_{600}$, $\mathrm{E} 16_{550}, \mathrm{P} 12_{650}$, and $\mathrm{AN6}_{900}$ were not linked.

\section{Discussion}

According to the results from testing segregating families, one recessive gene for resistance to brown spot disease was proposed, based on the inheritance ratios of hybrids from 'Clementine' (ss), and backcross families, and confirmed by the other families. The chi-square test with the 'Clementine' (ss) $\times$ LB\#8-10 (Ss) backcross population supported the hypothesis that resistance to the Shinn isolate was controlled by a single recessive allele inherited from 'Clementine' mandarin. One possible explanation for the distorted segregation in the reciprocal backcross could be that different cytoplasmic genes might play a role depending on the direction of the cross. Paternal mitochondrial effects have been previously proposed within citrus (Moreira et al., 1998). However, distorted segregation ratios have been observed in Citrus-Poncirus backcrosses (Cai et al., 1994; Durham et al., 1992; Weber et al., 2003). The distorted backcross segregation ratios do not contradict the evidence from several other crosses supporting the hypothesis that alternaria resistance is controlled by single recessive allele. Recessive alleles controlling plant disease resistance are rare among plants, but have been documented in pear and apple for resistance to other Alternaria species (Kozaki, 1976; Saito and Takeda, 1984).

In alternaria resistance tests performed, it was found that there were identical resistance ratings regardless of inoculation methods used (attached vs. detached; hand-sprayer vs. application of droplets by pipetter, data not shown). These results were in agreement with previous studies for evaluation of cultivar susceptibility (Kohmoto et al., 1979; Pegg, 1966; Solel and Kimchi, 1997). The conidia suspension spray method under sufficient humidity, at the earliest possible growing stage of the seedling progeny, will speed the selection efficiency. It allows for early discard of susceptible individuals and utilization of resources only for the evaluation of resistant hybrids. The resistance response of mandarin cultivars should be tested further with different $A$. alternata isolates (Solel and Kimchi, 1997), to be used in sexual hybridizations for transferring alternaria resistance gene(s) from the resistant cultivars to newly improved commercial cultivars (Schutte, 1993).
If it is absence of the dominant allele that confers $A$. alternata resistance, this dominant allele, AaM1, from LB\#8-10 (Ss) through 'Minneola' (SS) conferring brown spot susceptibility is in a coupling phase with AL $3_{1250}$ and P12 ${ }_{850}$ RAPD-PCR markers. In other words, the disease resistance conferred by the recessive allele for alternaria resistance from 'Clementine' (ss) is in repulsion with $\mathrm{AL} 3_{1250}$ and $\mathrm{P} 12_{850}$ markers. Why $\mathrm{AL} 3_{1250}$ and $\mathrm{P} 12_{850}$ did segregate in a $3: 1$ ratio $\left(66: 23\right.$ and $61: 28, \chi^{2}=0.03$ and 1.98, respectively, $P \geq 0.05)$, and $\mathrm{AN6}_{650}, \mathrm{~V} 3_{1500}, \mathrm{~S} 9_{800}$, and AL $3_{1600}$ showed 1:1 segregation $\left(\chi^{2}=1.90,2.91,1.36\right.$, and 1.36, respectively, $P \geq 0.05$ ) remains in question. If both parents are heterozygous for these markers, all markers must fit in ss $\times$ Ss ratio, suggesting that 'Clementine' is ss, and LB\#8-10 is Ss (Table $3)$. Selection against AL $3_{1250}$ or P $12_{850}$ markers theoretically should increase the efficiency of resistance breeding, by increasing the frequency of homozygous recessive individuals in the population (Kelly, 1995); however, the screening by application of conidial suspensions is less costly and labor intensive. In addition, since the RAPD markers are located at a substantial distance $(>10 \mathrm{cM})$ from the putative resistance locus, the likelihood of errors through MAS argues further against its use. Markers associated with the resistance allele would be very useful to identify heterozygous susceptible individuals, which are more valuable as breeding parents for resistance as well; unfortunately no markers were found to be linked to the $a a M 1$ allele.

The difficulty of finding RAPD markers closely linked to brown spot resistance region, even after screening so many primers, could be due to the difficulty for finding polymorphisms in the more narrow Citrus $\times$ Citrus background, compared with the result in the Citrus $\times$ Poncirus background. 


\section{Literature Cited}

Cai, Q., C.L. Guy, and G.A. Moore. 1994. Extension of the linkage map in Citrus using random amplified polymorphic DNA (RAPD) markers and RFLP mapping of cold-acclimation-responsive loci. Theor. Appl. Genet. 89:606-614.

Canihos, Y., T.L. Peever, and L.W. Timmer. 1998. Temperature, leaf wetness, and isolate effects on infection of Minneola tangelo leaves by Alternaria sp. Plant Dis. 83:429-433.

Deng, Z., S. Huang, and F.G. Gmitter, Jr. 1996. Simple and quick procedure for preparing citrus genomic DNA for PCR analysis. Proc. Intl. Soc. Citricult. 2:841-844.

Deng, Z., S. Huang, S. Xiao, and F.G. Gmitter, Jr. 1997. Development and characterization of SCAR markers linked to the citrus tristeza virus resistance gene from Poncirus trifoliata. Genome 40:697-704.

Durham, R.E., P.C. Liou, F.G. Gmitter, Jr., and G.A. Moore. 1992. Linkage of restriction fragment length polymorphisms and isozymes in citrus. Theor. Appl. Genet. 84:39-48.

Fang, D., C.T. Federici, and M.L. Roose. 1998. A high-resolution map of the citrus tristeza virus resistance gene region in Poncirus trifoliata (L.) Raf. Genetics 150:883-890.

Fang, D.Q. and M.L. Roose. 1999. A novel gene conferring citrus tristeza virus resistance in Citrus maxima (Burm.) Merrill. HortScience 34:334-335.

Gardner, J.M., Y. Kono, and J.L. Chandler. 1986. Bioassay and host-selectivity of Alternaria citri toxins affecting rough lemon and mandarins. Physiol. Mol. Plant Pathol. 29:293-304.

Gmitter, F.G., Jr., J.W. Grosser, and G.A. Moore. 1992. Citrus, p. 335-369. In: F. Hammerschlag and R.L. Litz (eds.). Biotechnology of perennial crops. CAB Intl., Wallingford, Oxon, U.K.

Gmitter, F.G., Jr., S.Y. Xiao, S. Huang, X.L. Hu, S.M. Garnsey, and Z. Deng. 1996. A localized linkage map of the citrus tristeza virus resistance gene region. Theor. Appl. Genet. 92:688-695.

Hutchison, D.J. 1985. Rootstock development screening and selection for disease tolerance and horticultural characteristics. Fruit Var. J. 39:21-25.

Kelly, J.D. 1995. Use of random amplified polymorphic DNA markers in breeding for major gene resistance to plant pathogenes. HortScience 30:461-465.

Kohmoto, K., K. Akimitsu, and H. Otani. 1991. Correlation of resistance and susceptibility of citrus to Alternaria alternata with sensitivity to host-specific toxins. Phytopathology 81:719-722.

Kohmoto, K., Y. Itoh, N. Shimomura, Y. Kondoh, H. Otani, M. Kodama, S. Nishimura, and S. Nakatsuka. 1993. Isolation and biological activities of two host-specific toxins from the tangerine pathotype of Alternaria alternata. Phytopathology 83:495-502.

Kohmoto, K., R.P. Scheffer, and J.O. Whiteside. 1979. Host selective toxins from Alternaria citri. Phytopathology 69:667-671.

Kono, Y., J.M. Gardner, Y. Suzuki, and S. Takeuchi. 1985. Plant phytoxins from Alternaria citri: The minor ACRL toxins. Phytochemistry 24:2869-2874.

Kozaki,I. 1976. Early screening for resistance to Alternaria in pear. Plant Breeding Abstr. 49:704.

Ling, P., L.W. Duncan, Z. Deng, D. Dunn, X. Hu, S. Huang, and F.G. Gmitter, Jr. 2000. Inheritance of citrus nematode resistance and its linkage with molecular markers. Theor. Appl. Genet. 100:1010-1017.
Lincoln, S.E., M.J. Daly, and E.S. Lander. 1993. Constructing genetic linkage maps with MAPMAKER/EXP Version 3.0: A tutorial and reference manual. A Whitehead Inst. for Biomedical Res. Tech. Rpt. $3^{\text {rd }}$ ed. Beta distribution 3B. Whitehead Inst., Cambridge, Mass.

Mestre, P.F., M.J. Asins, J.A. Pina, E.A. Carbonell, and L. Navarro. 1997. Molecular markers flanking citrus tristeza virus resistance gene from Poncirus trifoliata (L.) Raf. Theor. Appl. Genet. 94:458-464.

Michelmore, R.W., I. Paran, and R.V. Kesseli. 1991. Identification of markers linked to disease-resistance genes by bulked segregant analysis: A rapid method to detect markers in specific genomic regions by using segregating populations. Proc. Natl. Acad. Sci. USA 88:9828-9832.

Moreira, C., C.D. Chase, F.G. Gmitter, Jr., and J.W. Grosser. 1998. Mitochondrial genome organization in the progeny of a citrus intergeneric cross, p. 33-36. In: I.M. Moller, P. Gardestrom, K. Glimelius, and E. Glaser (eds.). Plant mitochondria: From gene to function. Buckhuys Publishers, Leiden, The Netherlands.

Pegg, K.G. 1966. Studies of a strain of Alternaria citri Pierce, the causal organism of brown spot of Emperor mandarin. Queensland J. Agr. Animal Sci. 23:15-28.

Porebski, S., L.G. Bailey, and B.R. Baum. 1997. Modification of a CTAB DNA extraction protocol for plants containing high polysaccharide and polyphenol components. Plant Mol. Biol. Rpt. 15:8-15.

Saito, K. and K. Takeda. 1984. Genetic analysis of resistance to Alternaria blotch (Alternaria mali Roberts) in apple. Studies on the breeding of the apple. VIII. (in Japanese with English summary). Jpn. J. Breed. 34:197-209

Schutte, G.C. 1993. Breeding of citrus cultivars resistant to Alternaria alternata: A review, p. 197-202. In: Etienne Rabe (ed.). Proc. IV World Conf. Intl. Soc. Citrus Nurserymen, Johannesburg, South Africa.

Solel,Z. and M. Kimchi. 1997. Susceptibility and resistance of citrus genotypes to Alternaria alternata pv. citri. J. Phytopathol. 145:389-391.

Stam, P. and J.W. van Ooijen. 1995. JOINMAPTM version 2.0: Software for the calculation of genetic linkage maps. DLO-Centre for Plant Breeding and Reproduction Research (CPRO-DLO). Wageningen, The Netherlands.

Timmer, L.W., T.L. Peever, Z. Solel, and K.Akimitsu. 2003. Alternaria diseases of citrus-Novel pathosystems. Phytopathol. Mediterr. 42:99-112.

Tozlu, I., C.L. Guy, and G.A. Moore. 1999. QTL analysis of $\mathrm{Na}^{+}$and $\mathrm{Cl}^{-}$accumulation related traits in an intergeneric $\mathrm{BC}_{1}$ progeny of Citrus and Poncirus under saline and nonsaline environments. Genome 42:692-705.

U.S. Department of Agriculture. 1998. Annual report. Bureau of Citrus Budwood Registration, Div. of Plant Industry, Florida Dept. of Agr. and Consumer Services, Winter Haven, Fla. FY 1997-1998.

Weber, C.A., G.A. Moore, Z. Deng, and F.G. Gmitter, Jr. 2003. Mapping freeze tolerance quantitative trait loci in a Citrus grandis $\times$ Poncirus trifoliata $\mathrm{F}_{1}$ pseudo-testcross using molecular markers. J. Amer. Soc. Hort. Sci. 128:508-514.

Welsh, J. and M. McClelland. 1990. Fingerprinting genomes using PCR with arbitrary primers. Nucl. Acids Res. 18:7213-7218.

Whiteside, J.O. 1976. A newly recorded Alternaria-induced brown spot disease on Dancy tangerines in Florida. Plant Dis. Rpt. 60:326-329.

Williams, J.G.K., A.R. Kubelik, K.J. Livak, A. Rafalsky, and S.V. Tingey. 1990. DNA polymorphisms amplified by arbitrary primers are useful as genetic markers. Nucl. Acids Res. 18:6531-6535. 